\title{
Resilience in intertidal rocky shore assemblages across the stress gradient created by emersion times
}

\author{
Rosa M. Viejo* \\ Departamento de Biología y Geología, Universidad Rey Juan Carlos, 28933 Móstoles, Madrid, Spain
}

\begin{abstract}
A key feature of intertidal marine systems is the well-defined gradient of environmental stress generated by tides. In this study, resilience, i.e. the speed of recovery along this gradient, was explored in a temperate rocky shore system. The purpose was to test whether there was a negative relationship between environmental stress and resilience, as suggested by some previous empirical studies. The rate of recovery of macroalgal assemblages following disturbance was assessed by comparing cleared and control plots at 4 different tidal heights at 3 sampling times. The results indicated that resilience was greater at higher levels of environmental stress, contrary to previously documented patterns. The number of potential colonisers also decreased at more stressful elevations. This difference in the size of the available pool of species could in itself make re-assembly simpler and faster at higher, harsher elevations. The influence of environmental stress on resilience is possibly dependent on the degree and characteristics of the stress factors and the traits of the particular species pool. During the course of this study, dramatic changes in control assemblages were detected, with occasional local extinctions of canopy-forming species. Even when naturally species-poor assemblages (such as those from higher tidal elevations in rocky shores) may show high resilience, impoverished systems feasibly exhibit a different behaviour. An insightful approach for future research would be to test the effect of non-random extinctions in assemblages naturally varying in the richness of potential colonisers.
\end{abstract}

KEY WORDS: Disturbance $\cdot$ Resilience $\cdot$ Environmental stress $\cdot$ Species pool $\cdot$ Rocky shores

\section{INTRODUCTION}

The influence of environmental context (e.g. degree of physical stress) on the mechanisms of community assembly and species coexistence is a central issue in ecology. Species that arrive at a site are eliminated or 'filtered' if they lack the physiological traits to cope with the prevailing abiotic conditions there. At higher environmental stress, the subset of the species pool passing through this abiotic filter is reduced relative to more benign environments. These differences in the size of the available species pool per se may influence community assembly and diversity patterns across environmental gradients (Houseman \& Gross 2006, Chase 2007). For instance, the smaller pool of species that can persist at harsher conditions may lead to higher site-to-site similarity among assemblages in stressful environments, whereas a higher number of potential colonists in benign environments may lead to highly variable communities (Chase 2007).

As a consequence of recent human-induced alterations in species richness, there is a renewed interest in evaluating the influence of diversity on emergent properties of communities and ecosystems, such as stability (McCann 2000, Hooper et al. 2005). Diversity generally enhances stability at the community level under a range of environmental conditions including stress (Worm \& Duffy 2003 and references therein). The linkages among environmental context, species richness and stability are multi-directional and can be viewed from different perspectives. Thus, several experiments have explored how changing the size of the species pool influences community stability and then how the community responds to environmental 
stress. On the other hand, comparative studies across sites often evaluate how the environmental context influences patterns of local richness and community stability given a particular species pool. Stability is itself a contentious concept in ecology and has many facets (Grimm \& Wissel 1997). One of them is resilience, which can be defined as the speed at which an ecological system returns to a reference condition, which is also dynamic, after a temporary disturbance (Grimm \& Wissel 1997).

Disturbance processes and recovery rates (i.e. resilience) have been extensively investigated in marine intertidal assemblages. The influence of the traits of disturbed patches (size, shape, timing of creation), of species (e.g. propagation mode, competitive abilities) and the interactions between patch and species traits on successional patterns and rates have been analysed in numerous intertidal communities (e.g. Berlow 1997, Airoldi 1998, Benedetti-Cecchi 2000, Dudgeon \& Petraitis 2001, see Sousa 2001 for a review). A key feature of these marine systems is the well-defined and severe gradient of environmental stress generated by tides (Steneck \& Dethier 1994, Brewer et al. 1997). Some studies have explored the variation in resilience across this steep gradient, often finding that resilience decreased at more stressful tidal heights (Brewer et al. 1997, Bertness et al. 2006, Schiel 2006, Crain et al. 2008). Recovery at these tidal levels was a very slow process and mostly dependent on habitat amelioration by ecosystem engineers.

In this experiment, I examined variation in resilience along the tidal gradient in a temperate rocky intertidal system. In hard substrata, the environmental stress for marine animals and seaweeds is related to emersion times. At higher tidal elevations, organisms undergo longer emersion periods and hence longer periods of desiccation and solar radiation, and higher temperatures (Raffaelli \& Hawkins 1996). I evaluated how quickly the assemblages recovered from disturbance by comparing the abundance and composition of species in cleared versus undisturbed control plots, across 4 tidal heights at different sampling times. To estimate potential variations in the available pool of species along the stress gradient, I also compared the number of taxa in recently disturbed plots among tidal heights. Previous research in the same area had analysed interactions among colonisers during succession (Viejo et al. 2008). My intention here was to test if the observed patterns were in accordance with results of previous empirical studies suggesting a negative effect of environmental stress on resilience. The results, which were contrary to this prediction, are discussed in terms of variations in the size of the available species pool and species traits along the environmental gradient.

\section{MATERIALS AND METHODS}

Study site. The study was carried out in Artedo $\left(43^{\circ} 34^{\prime} \mathrm{N}, 6^{\circ} 12^{\prime} \mathrm{W}\right)$, a rocky location on the northern coast of Spain facing NE and so partially protected from the predominant NW wave action (wave roses from the studied area are available on the web page of Puertos del Estado, www.puertos.es/en/oceanografia_y_ meteorologia/). Tides are semidiurnal and the maximum range is around $4.3 \mathrm{~m}$. Vertical zonation in this area has been previously described (Arrontes et al. 2004 and references therein). Briefly, the high shore between approximately 3 and $2.5 \mathrm{~m}$ above Lowest Astronomical Tide (LAT) is dominated by barnacles (Chthamalus spp.) and grazing gastropods of the genus Patella. Below this zone, undisturbed areas are mostly colonised by macroalgal assemblages. At the start of the experiment, the brown canopy-forming alga Fucus vesiculosus (L.) dominated between 2.5 and $2 \mathrm{~m}$ above LAT, whereas lower tidal levels from 1.7 to $0.6 \mathrm{~m}$ above LAT were dominated by Himanthalia elongata (L.) S.F. Gray with F. vesiculosus, and below this by Bifurcaria bifurcata R. Ross. Beneath the canopies of F. vesiculosus and $H$. elongata an understorey assemblage of crustose and turf-forming algae developed. Under the $B$. bifurcata canopy, abundant sediment was entrapped (pers. obs.) and understorey species were very scarce.

Experimental design. Experimental disturbances were performed in plots at 4 different tidal levels (High, Mid-high, Mid-low and Low levels), from 2.5 to $1.2 \mathrm{~m}$ above LAT. The 2 highest tidal levels (High and Mid-high) were located respectively at the high and low border of the zone fully dominated by Fucus vesiculosus, i.e. at $2.5( \pm 0.05)$ and $2.1( \pm 0.05) \mathrm{m}$ above LAT (average height values $\pm \mathrm{SE}, \mathrm{n}=4$ ). The Mid-low level was located in the middle zone where F. vesiculosus and Himanthalia elongata co-dominated, at $1.7( \pm 0.04) \mathrm{m}$. The Low level was placed in the area dominated by Bifurcaria bifurcata at $1.2( \pm 0.04) \mathrm{m}$ above LAT. The extent of daytime air exposure was predictably longer at the High level, and greater differences in time exposure between High and Low levels appeared in summer, roughly coinciding with higher air temperatures (see Viejo et al. 2008).

As timing of disturbance may affect the successional sequence and rate, the experimental manipulations were done on 2 different dates, in July 2000 and February 2001, hereafter named First and Second Trials. On each starting date, 6 plots of $30 \times 30 \mathrm{~cm}$ were initially chosen at random at each tidal height, and macroalgae and sessile animals were removed from those plots using a paint scraper and a metal brush until no visible fragments of algae and sessile animals remained. The fronds of canopy-forming algae around the plots were also trimmed so that they would not 
shade the plots. The size of the experimental plots was chosen within the range of those most frequently produced by natural disturbance events in the area. In August 2000, a qualitative survey of unmanipulated control areas was carried out and the dominant and accompanying species present in a total of 6 plots of $30 \times 30 \mathrm{~cm}$ at each tidal height were noted.

Disturbed plots were initially sampled periodically, every 2 mo during the first 8 mo of the experiment and every 4 to 8 mo until August 2002. I evaluated the recovery from disturbance by comparing the abundance and composition of species in disturbed plots to those assemblages in same-size controls. Control plots were selected at random within tidal heights at each sampling date. Disturbed plots and controls were compared on 3 different dates: September 2003, August 2005 and September 2007. Disturbed plots were roughly aged 2.5 to 3 yr (First and Second Trials), 4.5 to $5 \mathrm{yr}$ and 6.5 to $7 \mathrm{yr}$ on those respective sampling dates. Due to logistical constraints imposed by sampling schedules of other experiments, in 2003 and 2005 I used 4 and 5 replicates, respectively, per tidal height, trial and treatment (i.e. Disturbed in July 2000, Disturbed in February 2001 and Control). As assemblages from disturbed plots and controls at the High level had already converged by 2003 (see 'Results'), only Midhigh to Low levels were sampled in 2005. In 2007, the plots disturbed at different times (i.e. from different trials) presented similar assemblages at any shore height (see 'Results'). Hence, plots from different trials were pooled, and 4 Controls and 4 Disturbed plots (2 plots from each trial) were sampled at all tidal heights.

Sampling method. Percentage cover of algae and sessile animals (barnacles and spirorbids) was recorded using a $30 \times 30 \mathrm{~cm}$ PVC frame divided into 36 sub-quadrats of $5 \times 5 \mathrm{~cm}$. Percent covers of 100,75 , 50 or $25 \%$ were assigned to the most abundant taxa within each square. I assigned a cover of $5 \%$ to represent organisms with lower abundances. Final cover was obtained by averaging over the 36 estimates. Primary and secondary covers (i.e. cover of algae directly on the substratum and overstorey canopies, respectively) were estimated for canopy-forming species. When possible, algae were identified to species in the field, although some taxonomically difficult groups were assigned to higher categories. This was the case for the families Ceramiaceae, Delesseriaceae and Rhodomelaceae, and coralline crusts and soft crusts (freshly crustose algae). I considered 2 groups within the genus Ulva: foliose (U. rigida C. Agardh) and filamentous (U. intestinalis L. and U. clathrata [Roth] C. Agardh) forms. See Viejo et al. (2008) for a complete list of species.

Data analysis. Distance-based permutational multivariate analyses of variance (PERMANOVA, Anderson
2005) were used to analyse differences in the whole assemblage between disturbed plots and controls across shore heights (2 factors analysed: Treatment and Level) and between controls on different sampling dates (factors Date and Level). PERMANOVA tests the simultaneous response of several variables to 1 or more factors in an ANOVA experimental design on the basis of any distance measure using permutation methods (McArdle \& Anderson 2001). All multivariate analyses were based on Bray-Curtis dissimilarities on fourthroot transformed data. Each term in the analysis was tested using 9999 random permutations of the appropriate units (Anderson 2005). Fourth-root transformation was performed to down-weight the importance of highly abundant species in the dissimilarity coefficients and then taking both common and rare species into account for comparisons among treatments, i.e. disturbed versus control plots, or dates (Clarke et al. 2001). Permutational tests of multivariate dispersion (PERMDISP, Anderson 2004) were used to check the homogeneity in the average dissimilarities of samples from the central location of their group.

To visualise multivariate patterns, non-metric multidimensional scaling (nMDS) ordinations were made on each sampling date using PRIMER software (Clarke 1993, Clarke et al. 2001). Ordinations were made on the basis of Bray-Curtis dissimilarity matrix calculated for fourth-root transformed data. To simplify and better visualise the patterns, I examined centroids of each treatment and tidal level instead of individual samples. The centroids in multivariate space defined by the Bray-Curtis measure are not the arithmetic averages of the original variables (Anderson 2001). Therefore, to obtain the plots, I calculated principal coordinates from the full Bray-Curtis dissimilarity matrix among all pairs of samples and then the distance matrix of centroids from these coordinates using the PCO program (Anderson 2003). These coordinates were used as the input distance matrix for nMDS ordination. I used the SIMPER procedure (Clarke 1993) to identify the percentage contribution (\%) that each species or taxon made to the measures of the Bray-Curtis dissimilarity between disturbed plots and controls at each tidal height and trial. Species (or taxa) were selected as 'important' if they contributed to the first $50 \%$ of cumulative percentage of average dissimilarity between treatments within tidal levels and trials.

Univariate analyses (ANOVAs) were also used to examine differences in total percent cover among tidal heights and treatments (disturbed plots from different trials and controls). Prior to analyses, Cochran's $C$-test (Underwood 1997) was used to check the assumption of homogeneity of variances.

Species densities and 95\% confidence intervals were computed for 4 samples from sample-based rar- 
efaction curves (sensu Gotelli \& Colwell 2001) in disturbed and control plots, using EstimateS v.8 software (Colwell 2005). Species densities were calculated at 4 different sampling times: 6 mo after manipulation (data from January and August 2001 in the First and Second Trials, respectively), 2003, 2005 and 2007. Comparisons of species densities between shore heights and disturbed versus control plots were performed by examining whether the corresponding $95 \%$ confidence intervals overlapped (Colwell et al. 2004).

\section{RESULTS}

Recovery from initial disturbance was progressive across shore heights. In 2003, the assemblages from disturbed plots and controls had already converged at the High level but not lower on the shore (Fig. 1a, Table 1). Two years later, in 2005, recovery was evident in disturbed plots from 1 out of 2 trials at the Mid-high level (Table 1, C versus D1 p > 0.25). Moreover, there was a trend to recover for plots from 1 trial at the Mid-low level (Table 1, C versus D2 p > 0.05). However, disturbed plots at the Low level still differed from controls in 2005 (Fig. 1b, Table 1). Assemblages from plots disturbed at different times were similar by 2007 (PERMANOVA, $F_{1,8}=1.04 \mathrm{p}=0.433$ for Trial effect, non-significant interaction Trial $\times$ Level, $F_{3,8}=1.32, \mathrm{p}=$ 0.245). At this last sampling time, disturbed areas only differed from controls at the Low level (Fig. 1c, Table 1).

Differences detected in 2003 between disturbed plots and controls at the Mid-high level were only due to understorey species (Table 2). Lower on the shore, however, canopy-forming algae (Himanthalia elongata and Bifurcaria bifurcata) greatly contributed to the average dissimilarity between disturbed plots and controls at that time (Table 2). As time progressed, canopy-forming species gradually recovered lower on the shore, and then differences at the Mid-low level in 2005 were only related to understorey species (Table 2). Nevertheless, at the lowest tidal level, the recovery of the dominant $B$. bifurcata, though detectable, was rather slow (average percent covers increased from $<1 \%$ to $13 \%$ from 2003 to 2007). This species mostly contributed to the dissimilarities between disturbed plots and controls in 2007, in addition to Codium sp., which was more abundant in disturbed plots (Table 2).

Among the understorey taxa, soft and coralline crusts and the red turf-forming Gelidium pusillum were more abundant in disturbed plots than in controls from Mid-high to Low levels (Table 2). It is worth noting that both soft crusts and G. pusillum were abundant in controls at the High level (see Appendix 1 for average percent covers in control plots). Other species, such as the brown turf Cladostephus spongiosus, were
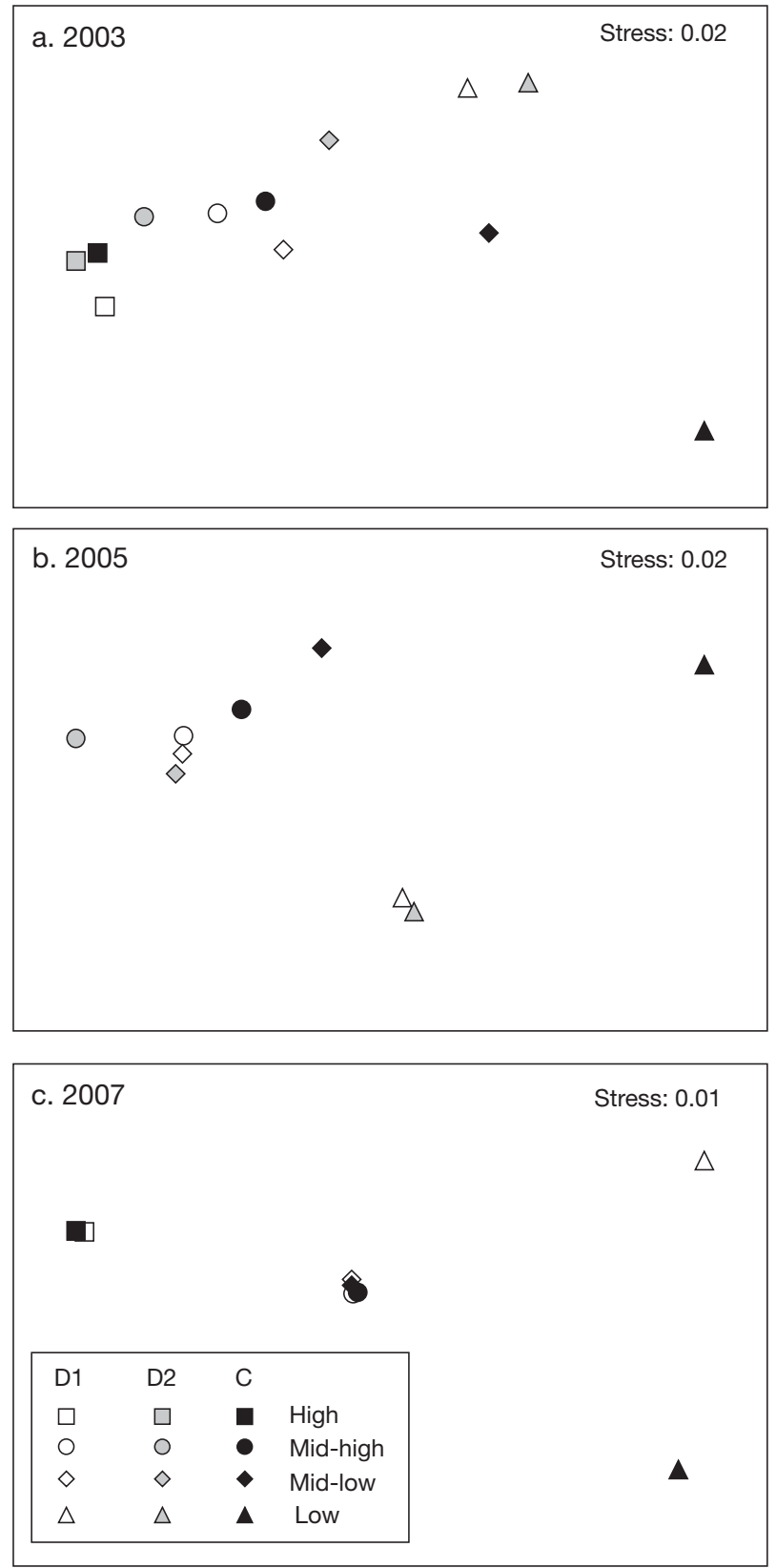

Fig. 1. Non-metric multidimensional scaling ordinations (nMDSs) on the basis of Bray-Curtis dissimilarity measure for the centroids of disturbed plots (D1: First Trial; D2: Second Trial) and controls (C) at the different shore heights. Data from (a) 2003, (b) 2005 and (c) 2007. In (b), only Mid-high, Mid-low and Low levels are included. In (c), disturbed plots from different trials were pooled (D in Table 1); see text

slow to colonise the clearings (Table 2). Corallina elongata showed different patterns depending on the tidal level. It was more abundant in controls farther up the shore, whereas at the Low level, its percent cover was higher in disturbed plots (Table 2). As mentioned above, abundant sediment was entrapped by Bifur- 
Table 1. PERMANOVA for differences in the macroalgal assemblages between treatments: controls (C) and disturbed plots from First (D1) and Second Trials (D2) at each tidal level. Data from 2003, 2005 and 2007. In 2007, plots from different trials were pooled and therefore only 2 treatments, controls (C) and disturbed plots (D), were considered (see text). N = 5 in $2003, n=4$ in 2005 and 2006. A posteriori pairwise comparisons are also shown. Multivariate dispersion was homogeneous among treatments and shore heights except in 2003 for the Mid-high level (PERMDISP, significant interaction Level $\times$ Treatment, $F_{6,48}=2.49$, $\mathrm{p}=0.0312$, average within-group dissimilarities in D1, D2 > C)

\begin{tabular}{|c|c|c|c|c|c|c|c|c|c|c|c|c|}
\hline \multirow{2}{*}{$\begin{array}{l}\text { Source of } \\
\text { variation }\end{array}$} & \multicolumn{4}{|c|}{2003} & \multicolumn{4}{|c|}{2005} & \multicolumn{4}{|c|}{2007} \\
\hline & $\mathrm{df}$ & MS & $F$ & $\mathrm{p}$ & $\mathrm{df}$ & MS & $F$ & $\mathrm{p}$ & df & MS & $F$ & $\mathrm{p}$ \\
\hline Treatment (T) & 2 & 3545.18 & 7.09 & $<0.001$ & 2 & 4282.07 & 7.85 & $<0.001$ & 1 & 983.34 & 1.84 & 0.136 \\
\hline Level (L) & 3 & 19454.33 & 38.89 & $<0.001$ & 2 & 11845.30 & 21.72 & $<0.001$ & 3 & 10389.30 & 19.39 & $<0.001$ \\
\hline $\mathrm{T} \times \mathrm{L}$ & 6 & 3420.48 & 6.84 & $<0.001$ & 4 & 2602.94 & 4.77 & $<0.001$ & 1 & 1564.74 & 2.92 & 0.009 \\
\hline Residual & 48 & 500.29 & & & 27 & 545.29 & & & 24 & 535.88 & & \\
\hline \multicolumn{13}{|c|}{ A posteriori comparisons } \\
\hline $\mathrm{T} \times \mathrm{L}$ & & & $t$ & $\mathrm{p}$ & & & $t$ & $\mathrm{p}$ & & & $t$ & $\mathrm{p}$ \\
\hline \multirow[t]{3}{*}{ High } & & S. D1 & 1.03 & 0.354 & & & & & & C vs. D & 1.04 & 0.400 \\
\hline & & s. D2 & 1.13 & 0.315 & & & & & & & & \\
\hline & & S. D2 & 1.16 & 0.274 & & & & & & & & \\
\hline \multirow[t]{3}{*}{ Mid-high } & & s. D1 & 1.69 & 0.054 & & C vs. D1 & 0.98 & 0.432 & & C vs. D & 0.98 & 0.456 \\
\hline & & s. D2 & 2.30 & 0.007 & & C vs. D2 & 2.23 & 0.020 & & & & \\
\hline & & S. D2 & 1.53 & 0.083 & & D1 vs. D2 & 1.61 & 0.075 & & & & \\
\hline \multirow[t]{3}{*}{ Mid-low } & & s. D1 & 3.12 & 0.002 & & C vs. D1 & 1.85 & 0.036 & & C vs. D & 0.82 & 0.626 \\
\hline & & s. D2 & 2.16 & 0.024 & & C vs. D2 & 1.58 & 0.086 & & & & \\
\hline & & s. D2 & 1.78 & 0.053 & & D1 vs. D2 & 0.66 & 0.883 & & & & \\
\hline \multirow[t]{3}{*}{ Low } & & S. D1 & 4.17 & $<0.001$ & & C vs. D1 & 4.29 & $<0.001$ & & C vs. D & 2.74 & 0.034 \\
\hline & & S. D2 & 4.13 & $<0.001$ & & C vs. D2 & 4.70 & $<0.001$ & & & & \\
\hline & & s. D2 & 2.03 & 0.011 & & D1 vs. D2 & 0.69 & 0.700 & & & & \\
\hline
\end{tabular}

Table 2. Species contributing to approximately the first $50 \%$ of cumulative percentage of average dissimilarity in pairwise comparisons between control (C) and disturbed (D) plots from the different trials (D1: First; D2: Second) and tidal levels (from Midhigh to Low) where significant ( $p<0.05)$ or marginally significant $(0.05<\mathrm{p}<0.06)$ differences were found (see Table 1). Data from 2003, 2005 and 2007. In 2007, disturbed plots from different trials were pooled (see text). For each species, the order of contribution (1: largest contribution) and the treatment for which cover was higher (C or D) are indicated. Nomenclature follows Guiry \& Guiry (2008)

\begin{tabular}{|c|c|c|c|c|c|c|c|c|c|c|c|}
\hline \multirow{3}{*}{$\begin{array}{l}\text { Tidal level: } \\
\text { Trial: }\end{array}$} & \multirow{2}{*}{\multicolumn{2}{|c|}{ Mid-high }} & \multirow{2}{*}{\multicolumn{2}{|c|}{$\begin{array}{l}2003- \\
\text { Mid-low }\end{array}$}} & \multirow{2}{*}{\multicolumn{2}{|c|}{ Low }} & \multirow{2}{*}{\multicolumn{2}{|c|}{$\begin{array}{l} \\
\text { Mid-hi Mid-lo }\end{array}$}} & \multirow{2}{*}{\multicolumn{2}{|c|}{ Low }} & \multirow{3}{*}{$\begin{array}{c}2007 \\
\text { Low } \\
\text { (pooled) }\end{array}$} \\
\hline & & & & & & & & & & & \\
\hline & D1 & D2 & D1 & D2 & D1 & D2 & D2 & D1 & D1 & D2 & \\
\hline \multicolumn{12}{|l|}{ Canopy-forming algae } \\
\hline Fucus vesiculosus (secondary cover) & & & & $4(\mathrm{D})$ & & & & & & & \\
\hline Himanthalia elongata (primary cover) & & & & & $3(\mathrm{D})$ & $2(\mathrm{D})$ & $5(\mathrm{C})$ & & $3(\mathrm{D})$ & 3 (D) & \\
\hline (secondary cover) & & & $1(\mathrm{C})$ & $1(\mathrm{C})$ & 5 (D) & 5 (D) & & & & & \\
\hline Bifurcaria bifurcata (secondary cover) & & & & & $1(\mathrm{C})$ & $1(\mathrm{C})$ & & & $1(\mathrm{C})$ & $2(\mathrm{C})$ & $2(\mathrm{C})$ \\
\hline Codium sp. (secondary cover) & & & & & & & & & & & 1 (D) \\
\hline \multicolumn{12}{|l|}{ Understorey species } \\
\hline Stypocaulon scoparium & & & & & & & & & & & $6(\mathrm{D})$ \\
\hline Cladostephus spongiosus & & & $6(\mathrm{C})$ & $5(\mathrm{C})$ & & & $2(\mathrm{C})$ & $4(\mathrm{C})$ & & & \\
\hline Colaconema daviesii & $2(\mathrm{D})$ & & & & & & & & & & \\
\hline Gelidium pusillum & $3(\mathrm{D})$ & & $5(\mathrm{D})$ & & & & $3(\mathrm{D})$ & $2(\mathrm{D})$ & & & \\
\hline Gigartina pistillata & & & & & 4 (D) & & & & & & \\
\hline Mastocarpus stellatus & $4(\mathrm{C})$ & $3(\mathrm{C})$ & $3(\mathrm{D})$ & $6(\mathrm{C})$ & & & $4(\mathrm{D})$ & & & & \\
\hline Soft algal crusts & & & 2 (D) & & $2(\mathrm{D})$ & & & $1(\mathrm{D})$ & $4(\mathrm{D})$ & 4 (D) & $5(\mathrm{D})$ \\
\hline Coralline crusts & & 4 (D) & & $3(\mathrm{D})$ & & & & 5 (D) & 5 (D) & & \\
\hline Corallina elongata & $1(\mathrm{C})$ & $1(\mathrm{C})$ & $4(\mathrm{C})$ & $2(\mathrm{C})$ & $6(\mathrm{D})$ & $3(\mathrm{D})$ & $1(\mathrm{C})$ & $3(\mathrm{C})$ & 2 (D) & 1 (D) & $7(\mathrm{D})$ \\
\hline Ceramiaceae & $5(\mathrm{C})$ & & & & & & & & & & \\
\hline Osmundea pinnatifida & & $5(\mathrm{C})$ & & & & 4 (D) & & & & & 4 (D) \\
\hline Ulva rigida & & 2 (D) & & & & & & & & & $3(\mathrm{D})$ \\
\hline Cumulative percentage of dissimilarity & 46.7 & 53.6 & 49.7 & 50.3 & 49.9 & 50.8 & 50.6 & 52.4 & 55.2 & 49.6 & 48.8 \\
\hline
\end{tabular}




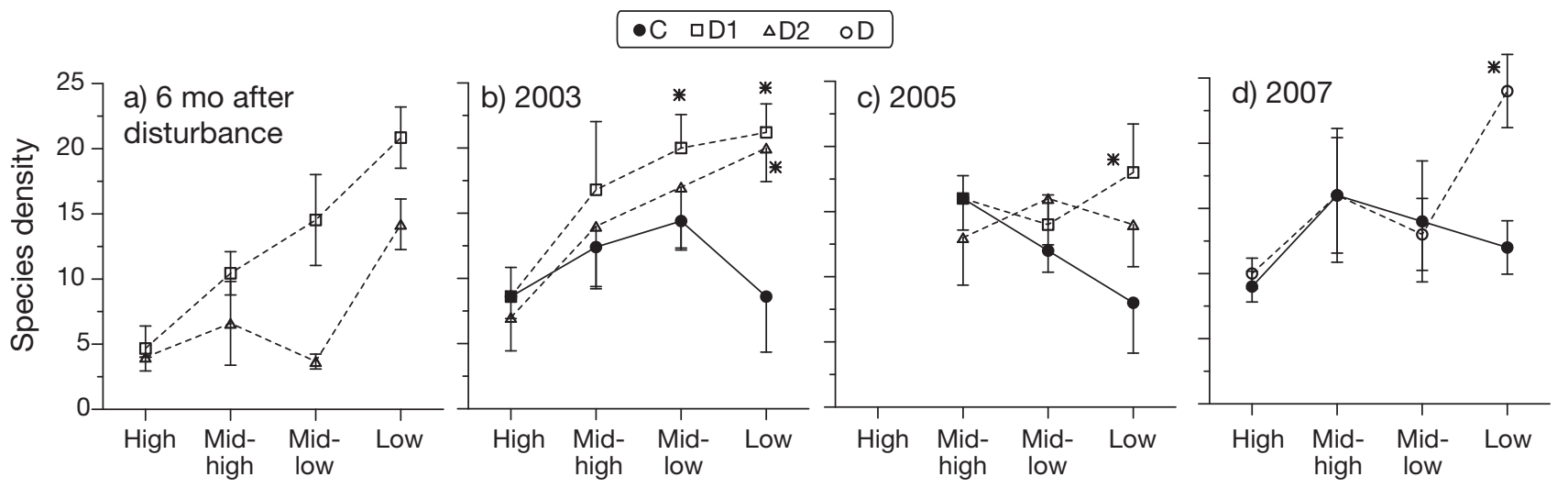

Fig. 2. Species/taxon densities in controls (C) and disturbed plots (D1 and D2: disturbed plots from First and Second Trials, respectively) across shore heights. Species densities are shown for 4 different dates: (a) 6 mo after initial disturbance, (b) 2003, (c) 2005 and (d) 2007. In (a), only data from disturbed plots are shown. In 2007, disturbed plots (D) from different trials were pooled (see text). Mean values $\pm 95 \%$ confidence intervals are shown, $\mathrm{n}=4$. Asterisks indicated significant differences (lack of overlap in confidence intervals) between controls and disturbed plots (either from 1 trial or both)

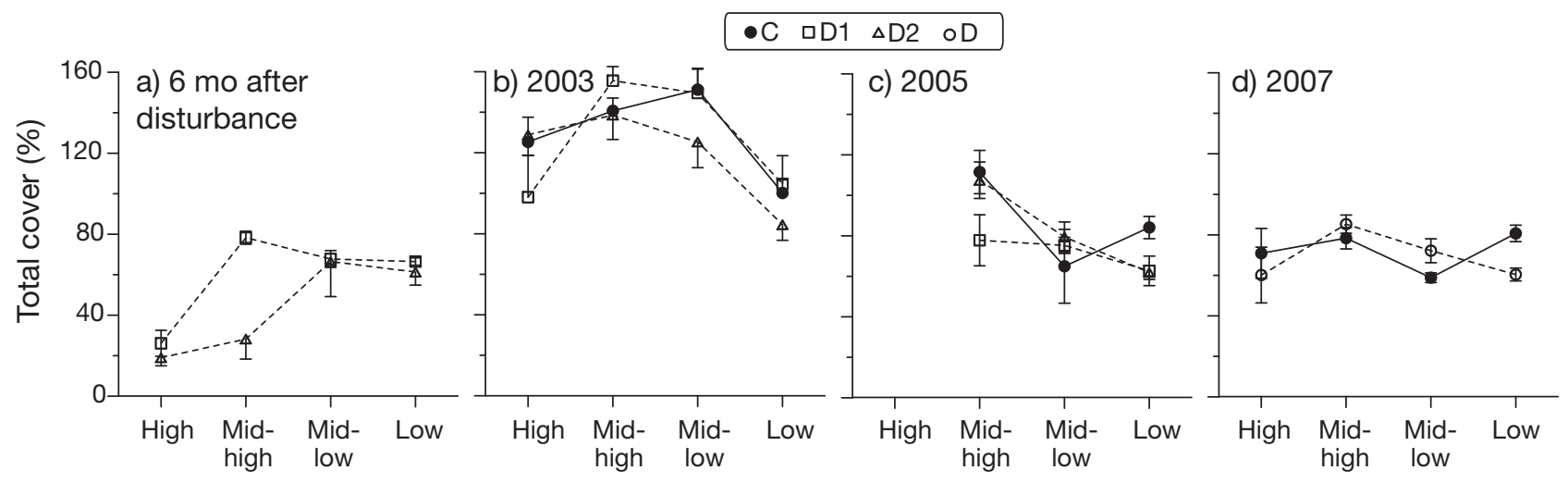

Fig. 3. Total percent cover in disturbed plots (D) and controls (C) at different shore heights (mean values $\pm S E$ are shown, $n=4$ ). Data from: (a) 6 mo after disturbance, (b) 2003, (c) 2005 and (d) 2007. D1 and D2: disturbed plots from the First and Second Trials

caria bifurcata and a very small percentage of understorey species (average values $<1 \%$ ) was recorded at this height in controls (Appendix 1).

Taxon density (number of taxa per area) generally increased in disturbed plots from higher to lower tidal levels from the early stages following experimental disturbance (Fig. 2). With the exception of Cirripedia and Cyanophyta, any taxon appearing in disturbed plots farther up the shore was also present at lower levels (see Viejo et al. 2008 for the complete list of species). Hence, the increase in taxon densities across shore heights in disturbed plots was due to the addition of species/taxa without replacements. The differences between disturbed plots and controls also tended to increase from High to Low levels, although these differences were only significant at the 2 lowest levels in 2003 (Fig. 2b). In 2005 and 2007, these differences only remained at the Low level (Fig. 2c,d). Total percent cover did not follow this trend to gradually increase from High to Low tidal levels, nor were there significant differences between disturbed plots and controls at any shore height (Fig. 3, ANOVAs for the effect of Treatment and Treatment $\times$ Tidal level, $\mathrm{p}>$ 0.10 , see Appendix 2 for complete analyses).

Control assemblages experienced drastic changes through the period of the study, especially from High to Mid-low levels (Table 3, percent covers in Appendix 1). Farther up the shore there was a decline in the size of Fucus plants (as shown by changes in the dominance of secondary to primary cover; Table 4, Appendix 1), a reduction in the abundance of the erect gametophyte Mastocarpus stellatus and an increase of Gelidium pusillum cover (percent covers in Appendix 1). Lower on the shore there was a drastic reduction in the abundance of Himanthalia elongata and Corallina elongata and an increase in filamentous 
Table 3. PERMANOVA for differences in the macroalgal assemblages between controls at different sampling times (2003, 2007) and tidal levels, $\mathrm{n}=4$. A posteriori pairwise comparisons are also shown. Multivariate dispersion was homogeneous across shore levels and between dates

\begin{tabular}{|c|c|c|c|c|c|c|c|c|}
\hline $\begin{array}{l}\text { Source of } \\
\text { variation }\end{array}$ & $\mathrm{df}$ & MS & $F$ & $\mathrm{p}$ & \multicolumn{2}{|c|}{$\begin{array}{l}\text { A posteriori comparisons } \\
\text { Year } \times \text { Level }\end{array}$} & $t$ & $\mathrm{p}$ \\
\hline Date & 1 & 10922.25 & 23.61 & $<0.001$ & High & 2003 vs. 2007 & 2.53 & 0.031 \\
\hline Level & 3 & 13537.59 & 29.27 & $<0.001$ & Mid-high & 2003 vs. 2007 & 3.90 & 0.027 \\
\hline Date $\times$ Level & 3 & 2460.04 & 5.32 & $<0.001$ & Mid-low & 2003 vs. 2007 & 4.39 & 0.029 \\
\hline Residual & 24 & 462.49 & & & Low & 2003 vs. 2007 & 1.59 & 0.058 \\
\hline
\end{tabular}

Table 4. Species contributing to approximately the first $50 \%$ of cumulative percentage of average dissimilarity in pairwise comparisons between controls on different sampling dates $(2003,2007)$ within tidal levels where significant $(\mathrm{p}<$ $0.05)$ or marginally significant $(0.05<\mathrm{p}<0.06)$ differences were found. For each species, the order of contribution and the year $(2003,2007)$ for which cover was higher are indicated (1: largest contribution)

\begin{tabular}{|c|c|c|c|c|}
\hline Tidal level & High & Mid-high & Mid-low & Low \\
\hline \multicolumn{5}{|l|}{ Canopy-forming algae } \\
\hline $\begin{array}{l}\text { Fucus vesiculosus (primary cover) } \\
\text { (secondary cover) }\end{array}$ & $\begin{array}{l}2(2007) \\
1(2003)\end{array}$ & $\begin{array}{l}5(2007) \\
2(2003)\end{array}$ & 4 (2003) & \\
\hline \multicolumn{2}{|l|}{$\begin{array}{l}\text { Himanthalia elongata (primary cover) } \\
\text { (secondary cover) }\end{array}$} & & $\begin{array}{l}5(2003) \\
1(2003)\end{array}$ & $1(2003)$ \\
\hline \multicolumn{5}{|l|}{ Understorey species } \\
\hline Gelidium pusillum & $3(2007)$ & $3(2007)$ & & \\
\hline Mastocarpus stellatus & 4 (2003) & $1(2003)$ & & \\
\hline Corallina elongata & & & 3 (2003) & $4(2003)$ \\
\hline Ceramiaceae & & & & $2(2007)$ \\
\hline Ulva spp. (filamentous forms) & & $4(2007)$ & $2(2007)$ & $3(2007)$ \\
\hline $\begin{array}{l}\text { Cumulative percentage } \\
\text { of dissimilarity }\end{array}$ & 58.0 & 55.8 & 48.4 & 49.9 \\
\hline
\end{tabular}

forms of Ulva (Table 4, Appendix 1). Assemblages from Mid-high and Mid-low levels became more similar through time (compare control plots from these shore heights in Fig. 1a-c). Overall, total percent cover in controls experienced a significant reduction during this period, especially from High to Mid-low levels (Fig. 3, ANOVA for total cover data in 2003 and 2007 , interaction Year $\times$ Level, $F_{3,24}=7.41, \mathrm{p}=0.001$; SNK test, High to Mid-low levels in 2003 higher than the rest).

\section{DISCUSSION}

\section{Resilience and the environmental context}

Results of this study show that recovery from disturbance was faster farther up the shore, i.e. resilience was higher at higher levels of abiotic stress. The observed differences in resilience across the stress gradient could be partially attributed to the identity of dominant species and their differences in traits such as growth and recruitment rates. Hence, the seaweed
Bifurcaria bifurcata, which monopolises space at the lowest tidal elevation, was slower to re-colonise clearings than Himanthalia elongata and especially Fucus vesiculosus, which dominated farther up the shore (Viejo et al. 2008, this study). Nevertheless, differences in resilience across shore heights were still evident without considering the lowest tidal level, i.e. when considering levels where the same canopyforming species dominated. These results were contrary to those observed in previous empirical investigations. For example, Brewer et al. (1997) found that rates of recovery from disturbance were slower at higher stressful elevations in salt marsh systems (higher stress occurred lower down the shore in these systems). More recently, Crain et al. (2008) found similar results in estuarine marshes at landscape-scale gradients of salinity, with faster rates of recovery in brackish and oligohaline marshes than in salt marshes. In rocky shore assemblages, slower recovery was detected at higher elevations (Bertness et al. 2006, Schiel 2006).

In this study, species densities (number of species per area) decreased in cleared plots from low to higher elevations. These changes were not merely due to variations in abundances across shore heights, as total abundances did not mirror the variation in species densities (for comments on the pitfalls of comparing species richness per unit area when abundances change, see Gotelli \& Colwell 2001). The observed richness trend suggests that fewer species were able to disperse into more stressful elevations and cope with the prevailing conditions there, i.e. go through dispersal and abiotic filters (sensu Houseman \& Gross 2006). Furthermore, a previous study in the same area showed that many species detected as macroscopic phases just lower down the shore were able to settle farther up (Ribas 2006). Hence, environmental filters rather than dispersal barriers could be limiting the pool of potential colonisers at higher, harsher tidal eleva- 
tions. The relevance of environmental filtering in determining local richness at sites with harsher abiotic conditions has been experimentally illustrated in recent research (Houseman \& Gross 2006).

Grazing pressure, which was mostly exerted by limpets, was only relevant at the highest tidal elevation (see Viejo et al. 2008). It could be argued that grazing reduced the number of colonisers at the highest tidal elevation. However, numbers of species were similar in the presence/absence of limpets (average values $\pm 95 \%$ confidence intervals: $5 \pm 1.7$ in the presence and $5 \pm 1.2$ in the absence of grazers; data from January 2001 in a grazing exclusion experiment, see Viejo et al. 2008 for details). It is also unlikely that grazing would accelerate recovery at the highest shore height, as limpets consumed the seaweed Fucus vesiculosus, dominating the assemblage at maturity.

I hypothesise that a reduced size in the available species pool makes re-assembly easier and faster at higher, harsher elevations, as long as environmental conditions are not too extreme. Certainly, physical conditions at the highest experimental elevation were not particularly severe for the dominant, canopy-forming seaweed Fucus vesiculosus (see comments in Viejo et al. 2008). Furthermore, other understorey taxa that were relatively abundant at the highest elevation, such as soft crusts and the red turf-forming alga Gelidium pusillum, are indeed representative of stressful or perturbed situations (Dethier 1994, Steneck \& Dethier 1994, Diez et al. 1999). Interestingly, these algae also colonised disturbed areas lower down the shore, although other species flourished at later phases in succession. The successional sequence thus became more complex/longer at more benign elevations, where the number of potential colonisers was higher than at more stressful elevations.

An alternative explanation for higher resilience at higher levels of abiotic stress could be the presence of changes in the sign and number of species interactions along the emersion gradient. If positive interactions among colonisers would dominate farther up the shore and negative interactions at more benign elevations, in accordance with the so-called 'stress-gradient hypothesis' (Bertness \& Callaway 1994), recovery could hypothetically speed up at stressful elevations. Results of a previous study in the same system indicated that different mechanisms of succession may operate simultaneously within a given successional sequence, independently of the shore height (Viejo et al. 2008). Furthermore, in the cases where recovery was slower at higher stressful elevations, facilitation among colonisers did dominate in harsh environments (Brewer et al. 1997, Bertness et al. 2006). I do not rule out, however, that a higher number of interactions among colonisers in more benign environments may retard recovery there, but I argue that this could be precisely related to the higher number of potential colonisers.

The influence of the size per se of the available pool of species, once sieved through the abiotic filter, on community assembly has recently been stressed by Chase (2007). The results of his experiment indicated that differences in the size of the pool could make community assembly rather deterministic in harsh environments, independently of the process of assembly, whereas it became more variable in benign habitats. Results of the present study did not support the presence of a lower predictability in successional patterns in more benign environments: assemblages from disturbed plots did not show higher dispersion lower down the shore (PERMDISP results in Table 1). As mentioned above, the observed divergence between perturbed plots and controls at the lowest tidal height may rather reveal a transient phase within a longer successional pathway.

I examined the influence of the environmental context on stability, focusing on how physical stress could positively affect community resilience by filtering the available pool of species. Other studies investigating environmental context-diversity-stability relationships used different perspectives. For example, Allison (2004) manipulated the size of the species pool to test the influence of richness on the resilience of intertidal communities in response to different stress levels. It is important to precisely define the viewpoint taken in each particular study. The seeming contradictions observed in different studies on the same topic (e.g. diversity-stability debate) are partially due to differences in the perspectives and the concepts considered (e.g. Worm \& Duffy 2003). The conflicting results between this and previous empirical studies with similar perspectives, however, reflect variability in the influence of environmental stress on resilience. This influence is likely to be dependent on the degree and characteristics of stress factors and the characteristics of the available species pool, i.e. how stressful is the environment for the particular pool of colonisers. Hence, in Patagonian rocky shores, where resilience is low at higher shore elevations, the level of physical stress is extreme and the performance of species is compromised and entirely dependent on ecosystem engineering (Bertness et al. 2006). In intertidal reef platforms of southern New Zealand, the slower recovery detected at mid-shore levels in relation to lower tidal elevations was attributed to the vulnerability of early life stages of the dominant fucoid, Hormosira banksii, to physical conditions at that height (Schiel 2006). In the present study, environmental stress acts as a filter in the species pool, rather than greatly influencing the performance of species passing through this filter, particularly those canopy-forming algae, 
playing a key role in the recovery of the assemblage. As explained above, the abiotic environment at the highest experimental elevation was not particularly severe for the dominant Fucus vesiculosus (further comments in Viejo et al. 2008). As an additional remark, it is worth mentioning that in previous studies (Brewer et al. 1997, Bertness et al. 2006, Crain et al. 2008), recovery was generally considered as the reestablishment of any assemblage, independent of potential differences between assemblages in disturbed and control areas. It would be interesting to determine if by using the criteria adopted in this study (similarity of control and disturbed areas), analogous patterns would emerge.

\section{Changes in intertidal assemblages and potential effects on resilience}

Resilience can be defined as the speed at which an ecological system returns to a reference condition, which is dynamic, after a temporary disturbance (Grimm \& Wissel 1997). Evident shifts were detected in control assemblages during the course of this study, with clear reductions in canopy-forming seaweeds and variations in understorey species. The understorey algae increasing in abundance were those typical of disturbed situations, such as Gelidium pusillum and Ulva spp. (Diez et al. 1999), whereas declines were observed for Corallina elongata and the erect form of Mastocarpus stellatus. The results of a previous study indicated that these last species develop preferentially under the protection of canopies (Viejo et al. 2008 and references therein). Overall, total abundance in intertidal assemblages clearly decreased through time. Resilience should be understood as the rate of convergence of disturbed and 'mature' assemblages that are also shifting.

The observed changes in intertidal assemblages were not restricted to the studied location, since similar alterations, including occasional local extinctions of canopy-forming seaweeds, were recently observed along a stretch of coast of about $100 \mathrm{~km}$ in the NW Iberian Peninsula (unpublished data). In this area, individuals of several canopy-forming species (especially Fucus spp. and Himanthalia elongata) looked as if they had been burned off, whereas sparse individuals with a healthy appearance remained solely in shaded places, e.g. under big boulders. This suggests that the observed alterations might be related to recent changes in climatic conditions; the study was conducted during some of the warmest years recorded since instrumental records began (IPCC 2007, Spanish Meteorological Agency, www.aemet.es/).

This study indicates that naturally species-poor assemblages, such as those from higher tidal eleva- tions in rocky shores, may show higher resilience. Yet, it is important to remark that depauperate systems feasibly exhibit a very different behaviour. Previous experimental studies illustrated the importance of species richness (e.g. Allison 2004) or species identity (e.g. Schiel 2006) on community resilience. The local, nonrandom extinction of species and the generation of species-poor intertidal systems may feasibly alter their resilience, especially if those species that are lost are canopy-forming algae acting as 'autogenic engineers' (sensu Lawton 1994), playing a vital role in associated assemblages (e.g. Benedetti-Cecchi et al. 2001, Lilley \& Schiel 2006, Schiel 2006). At this point, it is interesting to remark that repercussions of the loss of a particular species, e.g. a canopy-forming seaweed, on assemblage resilience would be more pronounced when this species has no functional equivalents in the system. In temperate rocky reef communities, previous work has reported both the presence and the absence of functional replacement after disturbance of canopyforming species (e.g. see results of Jenkins et al. 1999, 2004 versus Schiel 2006). An insightful approach for future research would be to test the effect of non-random extinctions on resilience of assemblages across environmental gradients, i.e. in assemblages naturally varying in the richness of the available species pool.

Acknowledgements. I thank S. R. Jenkins, F. Arenas and 4 anonymous reviewers for many thoughtful comments on the manuscript. Thanks also to S. R. Jenkins for improving my English.

\section{LITERATURE CITED}

Airoldi L (1998) Roles of disturbance, sediment stress and substratum retention on spatial dominance in algal turf. Ecology 79:2759-2770

Allison G (2004) The influence of species diversity and stress intensity on community resistance and resilience. Ecol Monogr 74:117-134

> Anderson MJ (2001) A new method for non-parametric multivariate analysis of variance. Austral Ecol 26:32-46

Anderson MJ (2003) PCO: a FORTRAN computer program for principal coordinate analysis. Department of Statistics, Auckland University

Anderson MJ (2004) PERMDISP: a FORTRAN computer program for permutational analysis of multivariate dispersions (for any two-factor ANOVA design) using permutation tests. Department of Statistics, University of Auckland

Anderson MJ (2005) PERMANOVA: a FORTRAN computer program for pemutational multivariate analysis of variance. Department of Statistics, University of Auckland

Arrontes J, Arenas F, Fernández C, Rico JM and others (2004) Effect of grazing by limpets on mid-shore species assemblages in northern Spain. Mar Ecol Prog Ser 277:117-133

Benedetti-Cecchi L (2000) Predicting direct and indirect interactions during succession in a mid-littoral rockyshore assemblage. Ecol Monogr 70:45-72

> Benedetti-Cecchi L, Pannacciulli F, Bulleri F, Moschella PS, Airoldi L, Relini G, Cinelli F (2001) Predicting the conse- 
quences of anthropogenic disturbance: large-scale effects of loss of canopy-algae on rocky shores. Mar Ecol Prog Ser 214:137-150

Berlow EL (1997) From canalization to contingency: historical effects in a successional rocky intertidal community. Ecol Monogr 67:435-460

Bertness MD, Callaway RM (1994) Positive interactions in communities. Trends Ecol Evol 9:191-193

Bertness MD, Crain CM, Silliman BR, Basterrica MC, Reyna MV, Hildago F, Farina JK (2006) The community structure of western Atlantic Patagonian rocky shores. Ecol Monogr 76:439-460

Brewer JS, Levine JM, Bertness MD (1997) Effects of biomass removal and elevation on species richness in a New England salt marsh. Oikos 80:333-341

> Chase JM (2007) Drought mediates the importance of stochastic community assembly. Proc Natl Acad Sci USA 104: 17430-17434

Clarke KR (1993) Non-parametric multivariate analyses of changes in community structure. Aust J Ecol 18:117-143

Clarke KR, Gorley RN, Warwick RM (2001) Changes in marine communities: an approach to statistical analysis and interpretation, 2nd edn. PRIMER-E, Plymouth

Colwell RK (2005) EstimateS: statistical estimation of species richness and shared species from samples. Version 8.0. User's Guide and application. Available at: http://purl. oclc.org/estimates

Colwell RK, Mao CX, Chang J (2004) Interpolating, extrapolating and comparing incidence-based species accumulation curves. Ecology 85:2717-2727

Crain CM, Albertson LK, Bertness MD (2008) Secondary succession dynamics in estuarine marshes across landscapescale salinity gradients. Ecology 89:2889-2899

Dethier MN (1994) The ecology of intertidal algal crusts: variation within a functional group. J Exp Mar Biol Ecol 177: $37-71$

Diez I, Secilla A, Santolaria A, Gorostiaga JM (1999) Phytobenthic intertidal community structure along an environmental pollution gradient. Mar Pollut Bull 38:463-472

Dudgeon S, Petraitis PS (2001) Scale-dependent recruitment and divergence of intertidal communities. Ecology 82: 991-1006

Gotelli NJ, Colwell RK (2001) Quantifying biodiversity: procedures and pitfalls in the measurement and comparison of species richness. Ecol Lett 4:379-391

Grimm V, Wissel C (1997) Babel, or the ecological stability discussions: an inventory and analysis of terminology and a guide for avoiding confusion. Oecologia 109:323-334

Guiry MD, Guiry GM (2008) AlgaeBase. World-wide electronic publication, National University of Ireland, Galway. Available at: www.algaebase.org

> Hooper DU, Chapin FS, Ewel JJ, Hector A and others (2005)
Effects of biodiversity on ecosystem functioning: a consensus of current knowledge. Ecol Monogr 75:3-35

Houseman GR, Gross KL (2006) Does ecological filtering across a productivity gradient explain variation in species pool-richness relationships? Oikos 115:148-154

IPCC (2007) Summary for policymakers. In: Solomon S, Qin D, Manning M, Chen Z, Marquis M, Averyt KB, Tignor M, Miller HL (eds) Climate change 2007: the physical science basis. Contribution of Working Group I to the Fourth Assessment Report of the Intergovernmental Panel on Climate Change. Cambridge University Press, Cambridge, NY, p 1-18

Jenkins SR, Hawkins SJ, Norton TA (1999) Direct and indirect effects of a macroalgal canopy and limpet grazing in structuring a sheltered intertidal community. Mar Ecol Prog Ser 188:81-92

Jenkins SR, Norton TA, Hawkins SJ (2004) Long term effects of Ascophyllum nodosum canopy removal on mid shore community structure. J Mar Biol Assoc UK 84:327-329

- Lawton JH (1994) What do species do in ecosystems? Oikos 71:367-374

Lilley SA, Schiel DR (2006) Community effects following the deletion of a habitat-forming alga from rocky marine shores. Oecologia 148:672-681

McArdle BH, Anderson MJ (2001) Fitting multivariate models to community data: a comment on distance-based redundancy analysis. Ecology 82:290-297

McCann KS (2000) The diversity-stability debate. Nature 405:228-233

Raffaelli D, Hawkins S (1996) Intertidal ecology. Chapman \& Hall, London

Ribas M (2006) Variabilidad en el reclutamiento y estructura de comunidades intermareales dominadas por macroalgas. $\mathrm{PhD}$ thesis, Universidad de Oviedo

Schiel DR (2006) Rivets or bolts? When single species count in the function of temperate rocky reef communities. J Exp Mar Biol Ecol 338:233-252

Sousa WP (2001) Natural disturbance and the dynamics of marine benthic communities. In: Bertness MD, Gaines SG, Hay ME (eds) Marine community ecology. Sinauer Associates, Sunderland, MA, p 85-130

Steneck R, Dethier M (1994) A functional group approach to the structure of algal-dominated communities. Oikos 69: 476-498

Underwood AJ (1997) Experiments in ecology. Their logical design and interpretation using analysis of variance. Cambridge University Press, Cambridge

> Viejo RM, Arenas F, Fernández C, Gómez M (2008) Mechanisms of succession along the emersion gradient in intertidal rocky shore assemblages. Oikos 117:376-389

Worm B, Duffy JE (2003) Biodiversity, productivity and stability in real food webs. Trends Ecol Evol 18:628-632 
Appendix 1. Species with percent covers $>1 \%$ at at least one of the sampling dates and tidal heights in control plots. Mean values (SE) are shown, $\mathrm{n}=4$. In 2005, data of foliose and filamentous forms of Ulva were pooled. Dominant (Dom) and accompanying (Acc) species recorded in a qualitative survey in August 2000 are also indicated. In the case of canopy-forming species, Dom or Acc was only noted in the most abundant cover (either primary or secondary)

\begin{tabular}{|c|c|c|c|c|c|c|c|c|c|c|c|c|c|c|c|}
\hline \multirow{2}{*}{ Tidal level: } & \multicolumn{3}{|c|}{ _ High } & \multirow{2}{*}{2000} & \multicolumn{2}{|c|}{ - Mid-high } & - & \multicolumn{3}{|c|}{ L Mid-low } & $\longrightarrow$ & \multicolumn{4}{|c|}{$\longrightarrow$ Low } \\
\hline & 2000 & 2003 & 2007 & & 2003 & 2005 & 2007 & 2000 & 2003 & 2005 & 2007 & 2000 & 2003 & 2005 & 2007 \\
\hline \multicolumn{16}{|l|}{ Canopy-forming algae } \\
\hline Fucus (primary cover) & & $\begin{array}{c}4.6 \\
(1.3)\end{array}$ & $\begin{array}{l}41.1 \\
(8.1)\end{array}$ & & $\begin{array}{c}2.1 \\
(0.5)\end{array}$ & $\begin{array}{c}6.9 \\
(1.8)\end{array}$ & $\begin{array}{l}42.5 \\
(8.5)\end{array}$ & & $\begin{array}{c}0.9 \\
(0.4)\end{array}$ & $\begin{array}{c}5.2 \\
(2.5)\end{array}$ & $\begin{array}{c}4.5 \\
(1.5)\end{array}$ & & $\begin{array}{c}0.0 \\
(0.0)\end{array}$ & $\begin{array}{c}0.0 \\
(0.0)\end{array}$ & $\begin{array}{c}0.0 \\
(0.0)\end{array}$ \\
\hline (secondary cover) & Dom & $\begin{array}{l}69.2 \\
(4.8)\end{array}$ & $\begin{array}{c}5.7 \\
(2.5)\end{array}$ & Dom & $\begin{array}{l}56.9 \\
(6.6)\end{array}$ & $\begin{array}{c}38.2 \\
(11.6)\end{array}$ & $\begin{array}{c}1.7 \\
(0.6)\end{array}$ & Acc & $\begin{array}{c}30.4 \\
(11.5)\end{array}$ & $\begin{array}{c}5.4 \\
(2.5)\end{array}$ & $\begin{array}{c}0.0 \\
(0.0)\end{array}$ & & $\begin{array}{c}0.0 \\
(0.0)\end{array}$ & $\begin{array}{c}0.0 \\
(0.0)\end{array}$ & $\begin{array}{c}0.0 \\
(0.0)\end{array}$ \\
\hline \multicolumn{2}{|c|}{ Himanthalia (primary cover) } & $\begin{array}{c}0.0 \\
(0.0)\end{array}$ & $\begin{array}{c}0.0 \\
(0.0)\end{array}$ & Acc & $\begin{array}{c}0.8 \\
(0.5)\end{array}$ & $\begin{array}{c}2.1 \\
(1.5)\end{array}$ & $\begin{array}{c}0.0 \\
(0.0)\end{array}$ & & $\begin{array}{c}6.5 \\
(1.7)\end{array}$ & $\begin{array}{c}4.0 \\
(2.0)\end{array}$ & $\begin{array}{c}0.0 \\
(0.0)\end{array}$ & Acc & $\begin{array}{c}0.3 \\
(0.3)\end{array}$ & $\begin{array}{c}0.1 \\
(0.1)\end{array}$ & $\begin{array}{c}0.0 \\
(0.0)\end{array}$ \\
\hline \multicolumn{2}{|l|}{ (secondary cover) } & $\begin{array}{c}0.0 \\
(0.0)\end{array}$ & $\begin{array}{c}0.0 \\
(0.0)\end{array}$ & & $\begin{array}{c}0.7 \\
(0.7)\end{array}$ & $\begin{array}{c}0.0 \\
(0.0)\end{array}$ & $\begin{array}{c}0.0 \\
(0.0)\end{array}$ & Dom & $\begin{array}{c}38.3 \\
(13.3)\end{array}$ & $\begin{array}{c}0.0 \\
(0.0)\end{array}$ & $\begin{array}{c}0.0 \\
(0.0)\end{array}$ & & $\begin{array}{l}11.7 \\
(6.8)\end{array}$ & $\begin{array}{c}0.0 \\
(0.0)\end{array}$ & $\begin{array}{c}0.0 \\
(0.0)\end{array}$ \\
\hline \multicolumn{2}{|l|}{ Bifurcaria bifurcata } & $\begin{array}{c}0.0 \\
(0.0)\end{array}$ & $\begin{array}{c}0.0 \\
(0.0)\end{array}$ & & $\begin{array}{c}0.0 \\
(0.0)\end{array}$ & $\begin{array}{c}0.0 \\
(0.0)\end{array}$ & $\begin{array}{c}0.0 \\
(0.0)\end{array}$ & Acc & $\begin{array}{c}5.9 \\
(5.8)\end{array}$ & $\begin{array}{c}0.0 \\
(0.0)\end{array}$ & $\begin{array}{c}0.0 \\
(0.0)\end{array}$ & Dom & $\begin{array}{l}85.5 \\
(3.3)\end{array}$ & $\begin{array}{l}77.3 \\
(6.8)\end{array}$ & $\begin{array}{l}77.2 \\
(4.3)\end{array}$ \\
\hline \multicolumn{4}{|c|}{ Codium sp. (secondary cover) } & & & & & & & & & Acc & & & \\
\hline \multicolumn{16}{|l|}{ Understorey species } \\
\hline \multicolumn{2}{|l|}{ Cladostephus spongiosus } & $\begin{array}{c}0.0 \\
(0.0)\end{array}$ & $\begin{array}{c}0.0 \\
(0.0)\end{array}$ & Acc & $\begin{array}{c}0.0 \\
(0.0)\end{array}$ & $\begin{array}{l}10.3 \\
(9.2)\end{array}$ & $\begin{array}{c}0.7 \\
(0.7)\end{array}$ & Acc & $\begin{array}{c}2.1 \\
(0.9)\end{array}$ & $\begin{array}{l}10.4 \\
(9.6)\end{array}$ & $\begin{array}{c}0.0 \\
(0.0)\end{array}$ & Acc & $\begin{array}{c}0.1 \\
(0.1)\end{array}$ & $\begin{array}{c}5.4 \\
(2.0)\end{array}$ & $\begin{array}{c}0.5 \\
(0.3)\end{array}$ \\
\hline \multicolumn{2}{|l|}{ Gelidium pusillum } & $\begin{array}{c}2.1 \\
(1.4)\end{array}$ & $\begin{array}{c}5.5 \\
(2.3)\end{array}$ & & $\begin{array}{c}0.4 \\
(0.4)\end{array}$ & $\begin{array}{c}0.8 \\
(0.6)\end{array}$ & $\begin{array}{c}9.1 \\
(2.9)\end{array}$ & & $\begin{array}{c}0.0 \\
(0.0)\end{array}$ & $\begin{array}{c}0.0 \\
(0.0)\end{array}$ & $\begin{array}{c}6.1 \\
(2.4)\end{array}$ & & $\begin{array}{c}0.0 \\
(0.0)\end{array}$ & $\begin{array}{c}0.0 \\
(0.0)\end{array}$ & $\begin{array}{c}0.0 \\
(0.0)\end{array}$ \\
\hline Mastocarpus stellatus & Acc & $\begin{array}{l}12.3 \\
(5.4)\end{array}$ & $\begin{array}{c}2.0 \\
(0.3)\end{array}$ & Acc & $\begin{array}{l}34.0 \\
(6.7)\end{array}$ & $\begin{array}{l}12.6 \\
(4.9)\end{array}$ & $\begin{array}{c}0.5 \\
(0.3)\end{array}$ & Acc & $\begin{array}{c}3.8 \\
(3.4)\end{array}$ & $\begin{array}{c}4.1 \\
(1.7)\end{array}$ & $\begin{array}{c}0.2 \\
(0.2)\end{array}$ & & $\begin{array}{c}0.0 \\
(0.0)\end{array}$ & $\begin{array}{c}0.0 \\
(0.0)\end{array}$ & $\begin{array}{c}0.0 \\
(0.0)\end{array}$ \\
\hline Soft algal crusts & Acc & $\begin{array}{l}26.4 \\
(6.3)\end{array}$ & $\begin{array}{l}15.0 \\
(4.4)\end{array}$ & Acc & $\begin{array}{l}20.0 \\
(3.2)\end{array}$ & $\begin{array}{c}9.2 \\
(5.0)\end{array}$ & $\begin{array}{c}7.0 \\
(1.2)\end{array}$ & & $\begin{array}{c}0.4 \\
(0.3)\end{array}$ & $\begin{array}{c}0.2 \\
(0.2)\end{array}$ & $\begin{array}{r}12.8 \\
(5.5)\end{array}$ & & $\begin{array}{c}0.1 \\
(0.1)\end{array}$ & $\begin{array}{c}0.0 \\
(0.0)\end{array}$ & $\begin{array}{c}0.2 \\
(0.2)\end{array}$ \\
\hline Coralline crusts & Acc & & & Acc & & & & & & & & & & & \\
\hline Corallina elongata & Acc & $\begin{array}{c}0.2 \\
(0.2)\end{array}$ & $\begin{array}{c}0.0 \\
(0.0)\end{array}$ & Acc & $\begin{array}{l}22.4 \\
(6.7)\end{array}$ & $\begin{array}{l}25.3 \\
(4.9)\end{array}$ & $\begin{array}{c}1.3 \\
(0.8)\end{array}$ & Acc & $\begin{array}{l}59.8 \\
(5.5)\end{array}$ & $\begin{array}{c}29.5 \\
(17.2)\end{array}$ & $\begin{array}{c}0.8 \\
(0.3)\end{array}$ & Acc & $\begin{array}{c}0.9 \\
(0.6)\end{array}$ & $\begin{array}{c}0.1 \\
(0.1)\end{array}$ & $\begin{array}{c}0.4 \\
(0.2)\end{array}$ \\
\hline Ceramiaceae & & $\begin{array}{c}0.0 \\
(0.0)\end{array}$ & $\begin{array}{c}0.0 \\
(0.0)\end{array}$ & Acc & $\begin{array}{c}0.5 \\
(0.3)\end{array}$ & $\begin{array}{c}0.8 \\
(0.3)\end{array}$ & $\begin{array}{c}0.2 \\
(0.2)\end{array}$ & Acc & $\begin{array}{c}0.2 \\
(0.1)\end{array}$ & $\begin{array}{c}2.9 \\
(1.0)\end{array}$ & $\begin{array}{c}0.0 \\
(0.0)\end{array}$ & Acc & $\begin{array}{c}0.5 \\
(0.5)\end{array}$ & $\begin{array}{c}0.9 \\
(0.6)\end{array}$ & $\begin{array}{c}0.7 \\
(0.2)\end{array}$ \\
\hline Osmundea pinnatifida & Acc & & & Acc & & & & Acc & & & & & & & \\
\hline Ulva rigida (foliose) & & $\begin{array}{c}0.2 \\
(0.2)\end{array}$ & $\begin{array}{c}0.3 \\
(0.2)\end{array}$ & Acc & $\begin{array}{c}1.2 \\
(0.5)\end{array}$ & $\begin{array}{c}3.0 \\
(1.6)\end{array}$ & $\begin{array}{c}2.5 \\
(0.5)\end{array}$ & Acc & $\begin{array}{c}0.5 \\
(0.2)\end{array}$ & $\begin{array}{c}2.9 \\
(1.2)\end{array}$ & $\begin{array}{c}0.3 \\
(0.2)\end{array}$ & Acc & $\begin{array}{c}0.0 \\
(0.0)\end{array}$ & $\begin{array}{c}0.1 \\
(0.1)\end{array}$ & $\begin{array}{c}0.2 \\
(0.1)\end{array}$ \\
\hline Ulva spp. (filamentous) & & $\begin{array}{c}0.0 \\
(0.0)\end{array}$ & $\begin{array}{c}0.4 \\
(0.2)\end{array}$ & Acc & $\begin{array}{c}0.2 \\
(0.2)\end{array}$ & & $\begin{array}{c}9.1 \\
(2.5)\end{array}$ & Acc & $\begin{array}{c}0.0 \\
(0.0)\end{array}$ & & $\begin{array}{l}28.2 \\
(9.3)\end{array}$ & Acc & $\begin{array}{c}0.0 \\
(0.0)\end{array}$ & & $\begin{array}{c}0.7 \\
(0.2)\end{array}$ \\
\hline Chthamalus spp. & Acc & $\begin{array}{c}7.8 \\
(4.3)\end{array}$ & $\begin{array}{c}0.7 \\
(0.5)\end{array}$ & & $\begin{array}{c}0.0 \\
(0.0)\end{array}$ & $\begin{array}{c}0.0 \\
(0.0)\end{array}$ & $\begin{array}{c}0.0 \\
(0.0)\end{array}$ & & $\begin{array}{c}0.0 \\
(0.0)\end{array}$ & $\begin{array}{c}0.0 \\
(0.0)\end{array}$ & $\begin{array}{c}0.9 \\
(0.9)\end{array}$ & & $\begin{array}{c}0.0 \\
(0.0)\end{array}$ & $\begin{array}{c}0.0 \\
(0.0)\end{array}$ & $\begin{array}{c}0.0 \\
(0.0)\end{array}$ \\
\hline
\end{tabular}

Appendix 2. ANOVA for differences in total cover between Treatments (Disturbed plots from First and Second Trials and Controls) and Tidal Levels (High, Mid-high, Mid-low, Low) in 2003, $\mathrm{n}=5$; 2005, $\mathrm{n}=4$; and 2007, $\mathrm{n}=4$. In 2005, only 3 Tidal Levels (Mid-high to Low) were compared; in 2007, disturbed plots from different trials were pooled and then only 2 treatments, Disturbed and Controls, were considered (see text). Variances were homogeneous

\begin{tabular}{|c|c|c|c|c|c|c|c|c|c|c|c|c|}
\hline \multirow{2}{*}{$\begin{array}{l}\text { Source of } \\
\text { variation }\end{array}$} & \multicolumn{4}{|c|}{-2003} & \multicolumn{4}{|c|}{-2005} & \multirow[b]{2}{*}{$\mathrm{df}$} & \multirow{2}{*}{${ }_{\mathrm{MS}} 2007$} & \multirow[b]{2}{*}{$F$} & \multirow[b]{2}{*}{$\mathrm{p}$} \\
\hline & $\mathrm{df}$ & MS & $F$ & $\mathrm{p}$ & $\mathrm{df}$ & MS & $F$ & $\mathrm{p}$ & & & & \\
\hline Treatment $(\mathrm{T})$ & 2 & 547.46 & 0.81 & 0.449 & 2 & 719.52 & 1.90 & 0.169 & 1 & 58.45 & 0.26 & 0.618 \\
\hline Level (L) & 3 & 7805.70 & 11.60 & $<0.001$ & 2 & 3070.46 & 8.11 & $<0.001$ & 3 & 472.96 & 2.07 & 0.131 \\
\hline $\mathrm{T} \times \mathrm{L}$ & 6 & 968.42 & 1.44 & 0.219 & 4 & 746.48 & 1.97 & 0.128 & 3 & 482.21 & 2.11 & 0.125 \\
\hline Residual & 48 & 672.69 & & & 27 & 378.77 & & & 24 & 228.43 & & \\
\hline
\end{tabular}

